Notice of Memoirs.-J. C. Moberg-The Lias of Scania. 123

as in varions genera of Nantiloid shells, the earlier part of the shell was composed of a series of air-chambers, and that these chambers were periodically thrown off by natural truncation.

"Judging by the form of the lower part of the specimen under discussion, it may be presumed that the series of deciduous septa was considerably elongated, and that truncation took place at successive periods.

"The length of the specimen described is $48 \mathrm{~mm}$., and its greatest breadth $18 \mathrm{~mm}$.

“'This very instructive fossil was found at Karlstein, together with numerous examples of the same species, in the limestones of band $e 2$. It may be added that this specimen has been in our possession for many years, but it was not until the spring of 1875 that we decided to have a longitudinal section made at its posterior extremity [see Fig. 1], which resulted in the discovery of three unequally spaced septa."

Although, as we have seen, Barrande was the first to observe and to describe the deciduous septa of Ascoceras in Bohemia, Dr. Lindström's recent discovery of similar septa in Swedish specimens is extremely interesting, and warrants us in hoping that by still further research the initial chamber of Ascoceras inay be brought to light, and thus complete our knowledge of this singular genus.

\title{
NOTICES OF IMHMOIRS.
}

I.-Oy Lias i Sydöstra Skine. Af Joh. Chr. Moberg. Kongl. Svenska Vetenskaps-Akademiens Handlingar. Bdt. 22 , No. 6. STOCKHOLM, 1888.

On the Lias in South-Eastern Scania. By J. C. Moberg. 4 to. 86 pp. with One Map and Three lithographed Plates.

GROM several places in the neighbourhood of Kurremölla in the $f$ south-east of Scania, Dr. Moberg discovered in beds of shale and sandstone associated in places with thin beds of coal, a series of fossils differing materially from those nccurring in the Liassic strata of other parts of the same province. The forms which mostly belong to lamellibranchiate Mollusca are carefully described and figured in the present memoir. They number in all 64 species, of which 52 are determinable, and 25 new forms. From a comparison of the known forms, the author concludes that the Kurremölla Lias fauna represents the zones of Ammoniles Bucklandi, Am. zipihus, and Am. Jamesoni, and that although there is a considerable number of fossils belonging to the Lower Lias, yet the most characteristic forms indicate that it is equivalent to the lowest part of the Middle Lias. It is thus on the same horizon as the Lias of the Island of Bornbolm and higher in the series than the Liassic strata of the north-west of Scania.

G.J.H. 
II.-List of the Fossil Faunas of Sweden. Edited by the Palæontological Department of the Swedish State Museum (Natural History). II. Upper Silurian. Stockholm, 1888, Norstedt and Sons. 8 vo. $29 \mathrm{pp}$.

THIS second part of the List of Swedish fossils, prepared by Prof. 1 G. Lindström, contains the names of the species occurring in the Upper Silurian strata of that country. The principal locality in which rocks of this period are developed is the Isle of Grotland, from which place no fewer than 960 species are recorded, and, according to Prof. Lindström, this number will be considerably increased when all the fossil groups are thoroughly worked out. Of those already studied in detail the Crustacea number 133 species, the Gasteropoda 192 species, the Brachiopoda 150 species, and the Crinoidea 180 species. The Silurian strata in Gotland are ranged under eight divisions, corresponding approximately with the divisions of the same rocks in this country, and the range of each species in the different divisions is carefully noted. Of the other localities in which Silurian rocks occur in Sweden, those in the province of Scania have yielded 75 species, in Dalecarlia 22 species, and in Jemtland 48 species.

G. J. H.

\section{III. - Öfversigt af Sveriges Mesozoiska Bildningar. Af} Bernhand Lundgren. (Ur Lunds Universitets Årsskrift, Tom. xxiv.), Lund, 1888.

A Review of the Mesozorc Formations of Sweden. By Bernhard Lundgren. (From the Yearbook of the University of Lund.) 4to. $37 \mathrm{pp}$.

$\triangle \mathrm{S}$ is well known, the Mesozoic strata of Sweden are exposed $A$ in situ only in a very limited tract of the southern part of that country, and they are but very imperfectly represented by two groups of beds; a lower, belonging to the Trias and older beds of the Lias ; and an upper, belonging to the newer beds of the Cretaceons system. In the present memoir Prof. Lundgren discusses in detail the distribution, the petrographical characters and the fossil contents of these various beds, as well as their relationship to the corresponding strata in other countries. The lower series of beds are included in (I.) the Kagaröd-group, which is regarded as probab]y of Keuper age; and (II.), the Coal-bearing beds, of Rhætic and Liassic age. The interval between the Lias and the Upper Chalk is entirely unrepresented, and it is probable that the South of Sweden was a land surface at the time. The Cretaceous beds belong to the Lower and Upper Senonian and the Danian stages. A list of the literature on the subject is appended.

G. J. H. 